\title{
Teknologi Desain Alat Pencelupan Pewarnaan di UKM Batik Dewandaru di Kecamatan Wonosari Kabupaten Malang
}

\author{
Vika Annisa Qurrata ${ }^{1}$, Ermita Yusida $^{1}$, Sudjatmiko $^{2}$, Lustina Fajar ${ }^{1}$ \\ ${ }^{1}$ Departemen Ekonomi pembangunan Fakultas Ekonomi Universitas Negeri Malang \\ Jl. Semarang No.5, Malang, 65145, Indonesia \\ ${ }^{2}$ Departemen Teknik Mesin Fakultas Teknik Universitas Merdeka Malang \\ Jl. Terusan Raya Dieng No.62-64 Malang, 65146, Indonesia
}

\section{ARTICLE INFO:}

Received: 2020-08-04

Revised: 2020-9-26

Accepted: 2020-10-22

\section{Keywords:}

Batik dye machine;

Hollow iron; leve;

SS304

\section{ABSTRACT}

Batik Tulis Dewandaru UKM only does batik coloring. The method is done by dipping the batik into a tub and then shaking it by the operator, causing an awkward and less functional posture. Based on the above problems, the Community Service team provided a solution to implement dyeing and fixation technology. The first part is an oil drum made from Galvanized Steel Sheets JIS G3302 SGCC with a thickness of $1.8 \mathrm{~mm}$, a sufficient 20 liters volume. It is equipped with a stainless steel pipe roller SS 304. The second part is a frame

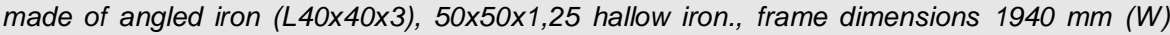
$x 660 \mathrm{~mm}(W) \times 1600 \mathrm{~mm}(\mathrm{H})$. The third part of the fabric support pipe with a total of 4 (cross), is made of SS 304 stainless steel pipe material, $1870 \mathrm{~mm}$ long. The fourth part of the player, made of SS 304 stainless steel pipe material, $325 \mathrm{~mm}$ long, doubles as a media to rotate the cloth and drain it. The tool, which weighs $75 \mathrm{~kg}$, makes the dyeing process shorter, which is 11 minutes. With the new tools, crafters can dye up to 35 fabrics to produce more fabric with perfect coloring.

(C) 2020 Published by University of Merdeka Malang. This is an open access article distributed under the CC BY-SA 4.0 license (https://creativecommons. org/licenses/by-sa/4.0/)

How to cite: Qurrata, V. A., Yusida, E., Sudjatmiko., \& Fajar, L. (2020). Teknologi Desain Alat Pencelupan Pewarnaan di UKM Batik Dewandaru di Kecamatan Wonosari Kabupaten Malang. Abdimas: Jurnal Pengabdian Masyarakat Universitas Merdeka Malang, 5(3), 228-238. https://doi.org/10.26905/abdimas.v5i3.4977

\section{PENDAHULUAN}

Karya seni yang bernilai tinggi warisan dari nenek moyang Indonesia adalah Batik merupakan bagian dari jati diri bangsa Indonesia yang telah diakui Dunia terkenal akan keindahannya. Batik dapat diartikan seni membuat bahan pakaian dimana di atas kain tersebut memiliki motif berupa tulisan dan titik. Batik juga dapat diartikan seni perwarnaan batik dimana motif-motif batik tersebut dibuat dari bahan malam yang dipanaskan, dimana bagian yang tidak terkena malam tersebut akan diberi warna sesuai yang diinginkan. Motif batik akan muncul dari bagian-bagian yang ditutupi malam tersebut. Pada catatan 
Kemenperin menyatakan dalam berita industri tahun 2012, bahwa berdasarkan data Badan Pusat Statistik (BPS) Indonesia mengimpor kain dan produk jadi batik dari Tiongkok sebanyak 1.037 ton bernilai USD 30 juta atau sekitar Rp285 miliar. Sebagian besar adalah batik printing (cetakan mesin). Primadhyta (2015) memberitakan bahwa BPS pada tahun 2013 mencatat Indonesia mengimpor sebanyak 282,3 ton produk batik dari berbagai negara dengan nilai mencapai USD5,2 miliar pada tahun 2013. Impor terbesar berasal Tiongkok sebesar 136,8 ton, senilai USD2,1 juta. Setelah itu disusul oleh Italia yang mengirim produk batiknya ke Tanah Air sebesar 43,1 ton, senilai USD 937,6 ribu. Negara lain yang mengekspor produk batiknya ke Indonesia adalah Hongkong, Korea Selatan, dan Jepang. Kondisi ini memaksa industri batik Indonesia untuk dapat bersaing dengan produk batik impor. Fakta tersebut cukup mengejutkan karena sebagai pemilik hak paten batik yang telah diberikan oleh UNESCO kepada Indonesia, tidak menjadikan Indonesia sebagai negara yang independen dalam peningkatan produksi batik dalam negeri. Kelompok Usaha Batik Tulis Dewandaru ini berdiri pada tahun 2017 dan bergerak di bidang produksi kain batik tulis khas Kabupaten Malang Jawa Timur. Bermula dari ketertarikan seorang ibu rumah tangga bernama Suharnik akan pembuatan batik, maka produksi batik ini mulai digagas dan diproduksi. Terdapat dua jenis yaitu batik yang di produksi di Kelompok Usaha Batik Tulis dan batik cap Dewandaru. Setelah kain batik diberi motif batik, kain akan diberi warna buatan atau warna alami. Proses produksi dilakukan secara manual dengan alat dan bahan yang terbatas. Usaha yang telah berjalan selama 2 tahun ini sudah mampu menarik minat warga sekitar. Hingga kini, Produksi kain batik tulis yang dihasilkan adalah 10 buah per bulan dengan harga rata-rata Rp 250.000 - Rp 1.000 .000 per lembar kain batik. Kisaran harga batik tulis cenderung sangat murah bila dibandingkan dengan harga batik tulis yang telah dipasarkan melalui pasar online maupun galeri dimana harganya bisa berkali lipat. Selain itu, terbatasnya produksi yang dilakukan tiap bulannya merupakan dampak masih minimnya modal yang digunakan dan pemasaran yang terbatas. Gambar 1 memperlihatkan proses pengerjaan batik tulis dan alat yang digunakan selama ini.
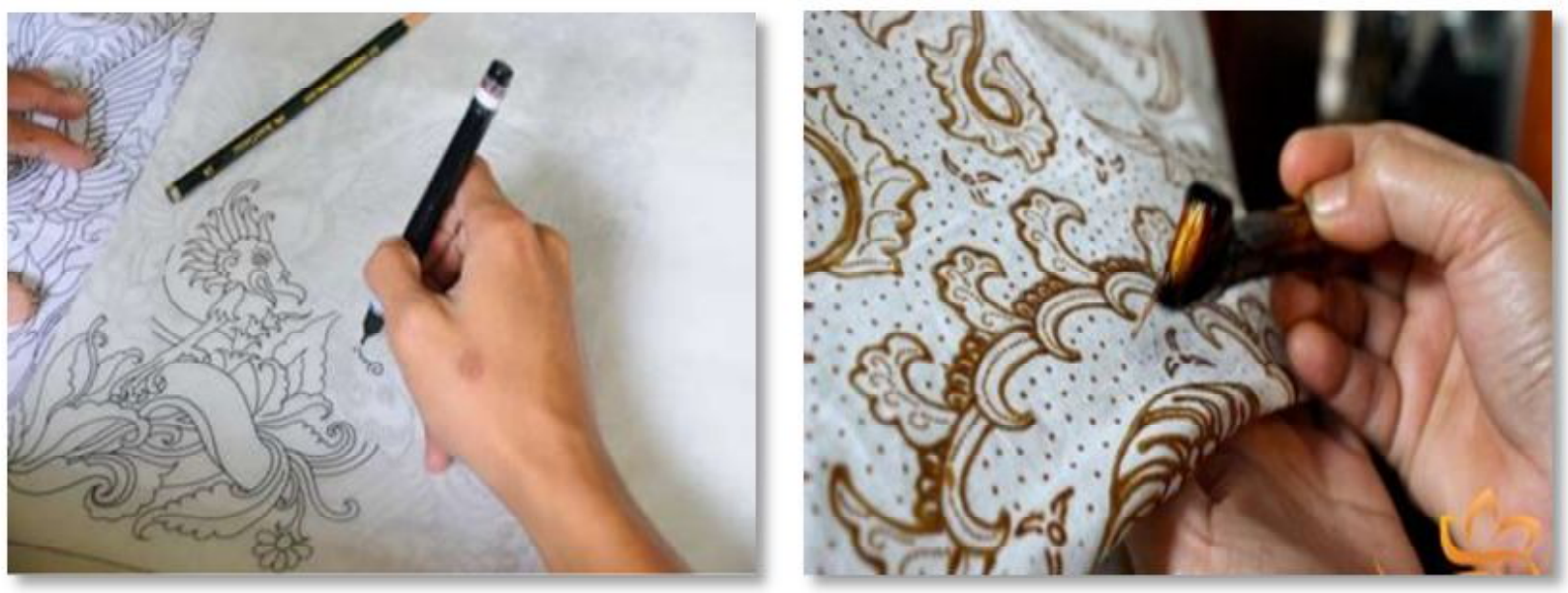

Gambar 1. Proses pembuatan pola dan pencantingan menggunakan lilin

Selama ini proses pencelupan dengan zat warna masih menggunakan napsol dan proses fiksasi dengan bahan pengunci yang dilakukan pada UKM masih sangat sederhana dengan cara mencelupkan batik ke sebuah drum plastik diperlihatkan pada Gambar 3 lalu digoyangkan oleh operator, cara pewarnaan ini menyebabkan postur canggung dan kurang fungsional yaitu menggunakan bak/drum plastik yang 
ABDIMAS: Jurnal Pengabdian Masyarakat Universitas Merdeka Malang Volume 5, No 3, November 2020: 228-238

dipotong separuh atau bak plastik. Menggunakan teknologi ini menjadikan proses pewarnaan dan proses fiksasi memakan waktu yang lama berulang-ulang serta pewarnaan yang dihasilkan lebih tidak merata, sehingga produksi batik yang dihasilkan sedikit.
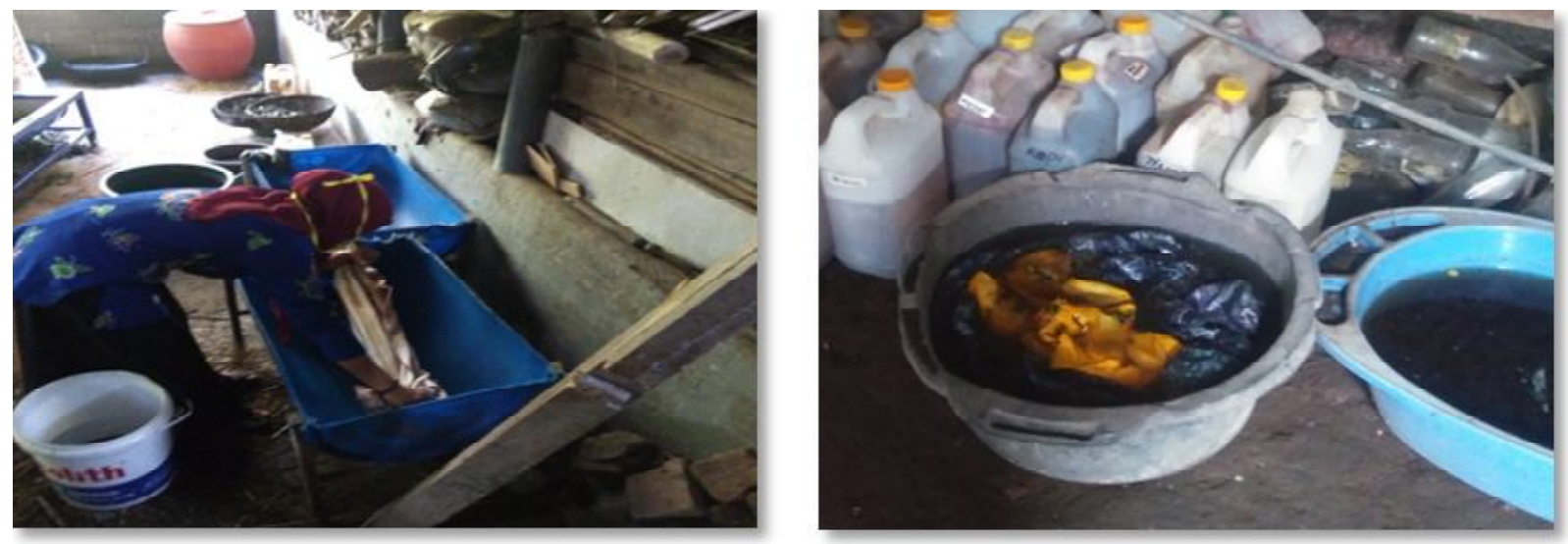

Gambar 2. Pencelupan kain batik pewarnaan/pencucian secara tradisional

Pesatnya perkembangan batik tersebut tidak diiringi dengan kemajuan peralatan - peralatan yang digunakan untuk proses produksi batik. Teknologi alat pencelupan dengan warna alami/pewarna buatan dan proses fiksasi yang akan didesain diharapkan hasil produk batik menjadi lebih rata serta meminimalisir waktu produksi. Capaian yang diinginkan dengan menggunakan teknologi baru hingga tahap prototype perlu dilakukan desain agar konsep yang dihasilkan UKM dapat diwujudkan secara nyata dan target spesifikasi yang sudah dipilih. Hal inilah yang menjadi rumusan masalah pengabdian agar dapat memenuhi spesifikasi teknis dan konsep akhir dari alat. Hasil yang dikeluarkan oleh pengabdian berupa material yang akan digunakan pada setiap bagian alat, mekanisme alat, gambar teknik hingga tahap cara perakitan alat dan produksi. Rincian perancangan merupakan tahapan untuk melengkapi spesifikasi dari produk meliputi geometri, material, dan toleransi. Komponen/elemen mesin mana yang akan dibeli dari pihak luar atau komponen mana yang akan diproduksi sendiri. Memutuskan komponen mana saja yang akan dibeli dari pihak luar dan komponen mana yang akan diproduksi sendiri. Tahapan terdiri dari output yaitu pencatatan pengendalian untuk produk berupa gambar pada file komputer tentang bentuk tiap komponen dan peralatan produksinya, spesifikasi komponen-komponen yang dibeli, serta rencana proses untuk pabrikasi dan perakitan produk (Ulrich, K. T \& Eppinger, S. D., 2012). Tujuan pengabdian dirumuskan bersama dengan UKM serta tim Pengabdian Kepada Masyarakat (PKM) hal ini untuk mendiskusikan desain teknologi alat pencelupan dengan warna alami/buatan dan proses fiksasi batik yang dapat memenuhi spesifikasi teknis dan konsep akhir yang sudah terseleksi. Gambar 3 memperlihatkan kerangka solusi pemecahan masalah, desain ini pengabdian mendapatkan data dari UKM batik yaitu konsep teknologi yang dilakukan di lapang. Untuk menentukan detail desain yang diinginkan didapatkan dari terlebih dahulu menentukan ukuran komponen yang sesuai dengan kondisi UKM, sehingga di dapatkan ukuran pasti setiap part saat proses perakitan. Dalam melakukan detail desain ini pula pengabdi menentukan material apa yang cocok digunakan pada masing-masing komponen yang dapat mendukung penggunaan alat saat digunakan. 


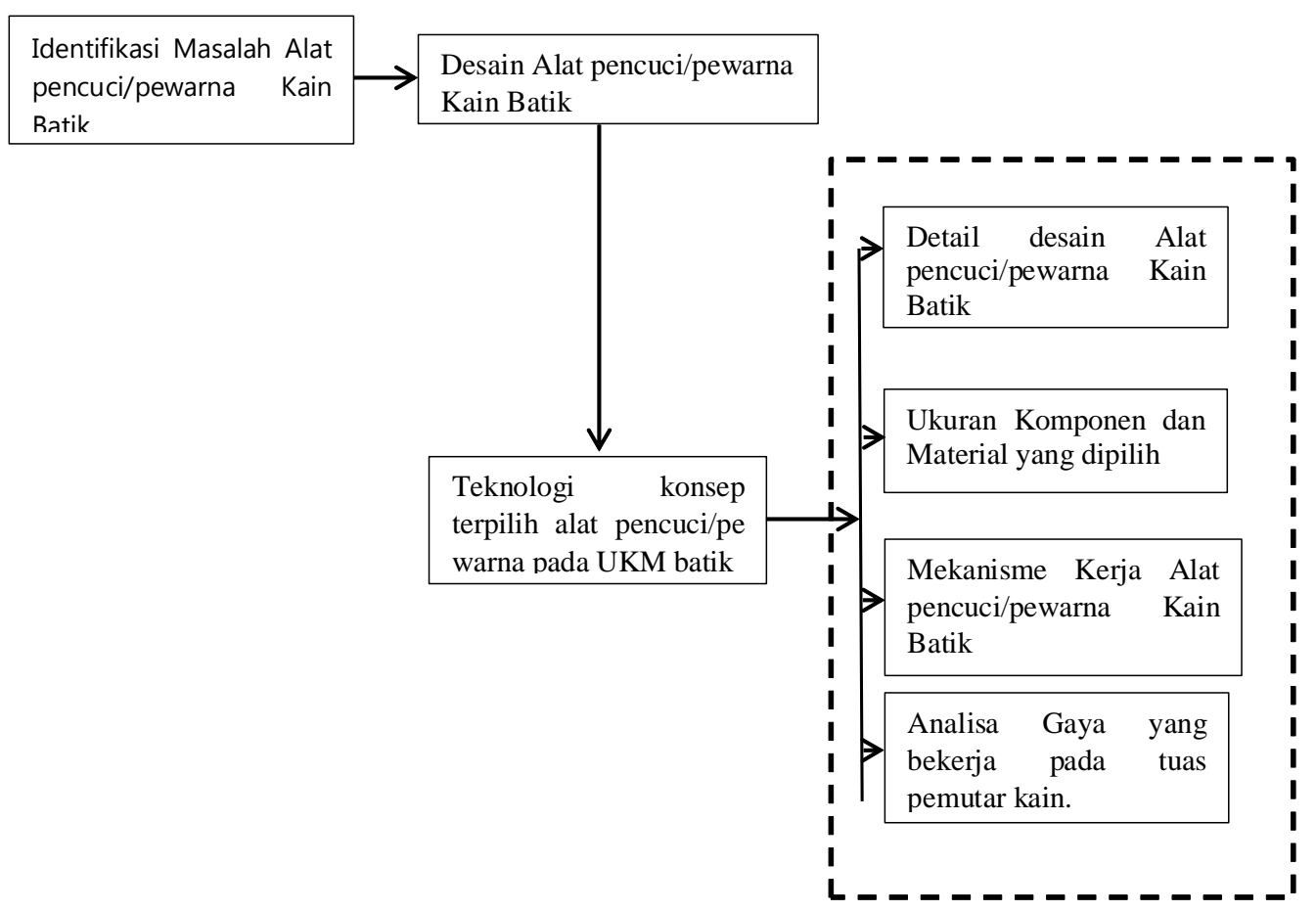

Gambar 3. Kerangka Solusi Teknologi Desain Alat Pencuci/Pewarna Batik

\section{METODE}

Guna mewujudkan teknolologi alat pencuci/pewarna batik, proses pendekatan dilakukan oleh tim pelaksana pada pelaksanaan Program Pengabdian Kemitraan Masyarakat (PKM) Universitas Negeri Malang (UM) di Desa Kampung baru kecamatan Wonosari Kabupaten Malang. Di dasarkan pada metode pendekatan sosial interaktif, yaitu berupa survei dan studi lapangan yang dilakukan team pelaksana serta hasil beberapa kunjungan terkait permasalahan-permasalahan yang dihadapi UKM batik, terutama kelompok masyarakat yang yang menjalani usaha rumahan Kelompok Usaha Batik Tulis dan batik cap Dewandaru. Pengabdian masyarakat ini dilakukan dengan terlebih dahulu melihat konsep dan target spesifikasi teknologi alat yang telah ditentukan oleh team pengabdi yang selanjutnya akan dilakukan detail desain oleh pengabdi yang meliputi ukuran komponen, material komponen dan gambar teknik dari teknologi alat. Pada Gambar 4 menyajikan metodologi pengabdian Teknologi alat pencuci/pewarna batik.

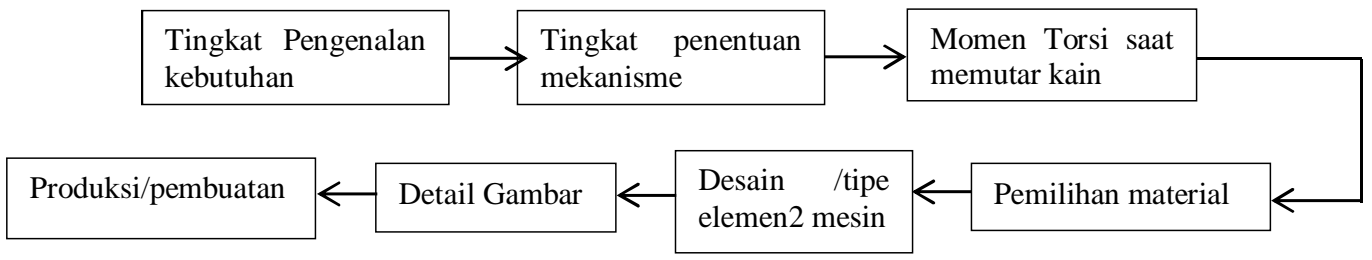

Gambar 4. Metodologi Pelaksanaan pembuatan Teknologi Alat Pencuci/Pewarna Batik 
ABDIMAS: Jurnal Pengabdian Masyarakat Universitas Merdeka Malang

Volume 5, No 3, November 2020: 228-238

Tabel 1 menyajikan material yang dipilih untuk Teknologi alat pencuci/pewarna batik guna menentukan jenis material yang akan dipakai pada setiap komponen yang telah ditentukan. Menurut Sonawan (2010), pemilihan jenis material ini mengacu terhadap tiga faktor yaitu dari faktor ketersediaan material, faktor kesesuaian material terhadap fungsi komponen dan faktor yang ketiga adalah biaya.

Tabel 1. Pemilihan Material yang Dipilih

\begin{tabular}{ll}
\hline \multicolumn{1}{c}{ Nama komponen } & \multicolumn{1}{c}{ Material } \\
\hline Kerangka & Besi hollow \\
Bak(Drum $1 / 2$ lingkaran) & Drum-Galvanis JIS G3302 \\
Tiang penyangga & Besi hollow \\
Tuas pengungkit $[\mathrm{L}]$ & Pipa Stainless steel \\
Roda & Roda karet \\
Pipa SS penopang kain "X" & Pipa hollow $20 \times 30 \times 3 \mathrm{~mm}$ \\
Pipa penopang kain bag. atas & SS-304 \\
\hline
\end{tabular}

Tabel 2 menyajikan pemilihan material yang akan dipakai untuk pembuatan Teknologi alat pencuci/ pencelupan pewarna batik, secara pasti digunakan untuk keperluan perakitan produksi alat tersebut.

Tabel 2. Pemilihan Material Secara Keseluruhan yang Digunakan Teknologi Alat Pencelupan Batik

\begin{tabular}{|c|c|c|c|c|}
\hline Nama komponen & $\begin{array}{r}\text { Tipe } \\
\end{array}$ & Dimensi (mm) & Jenis Material & Jumlah \\
\hline Kerangka & Besi hollow & $50 \times 50 \times 1.8$ & Besi & 1 set \\
\hline Bak & Drum-Galvanis & $560 \times 930 \times 0.65 ; 1850$ & JIS G3302 SGCC & 1 set \\
\hline Tiang penyangga & Besi hollow & $50 \times 50 \times 1.8 ; 1830$ & Besi & 2 buah \\
\hline Tuas pengungkit [L] & Pipa Stainless steel & Dia 3/4", 165;160;260 & SS-304 & 1 buah \\
\hline Roda & Roda karet & Dia $100 \times 70$ & Besi & 4 buah \\
\hline Penopang pipa kain [X] & Hollow & $30 \times 20 \times 1.8 ; 150 \times 150$ & Besi & 2 buah \\
\hline $\begin{array}{l}\text { Pipa penopang kain bag. } \\
\text { atas }\end{array}$ & Pipa Stainlessteel & Dia 3/4"; 1700 & SS-304 & 4 buah \\
\hline $\begin{array}{l}\text { Pipa penahan kain bag. } \\
\text { bawah }\end{array}$ & Pipa Stainlessteel & Dia 3/4 "; 1800 & SS-304 & 1 buah \\
\hline Lubang pembuangan & Pipa Stainlessteel & Dia 3/4 " ; 30 & SS-304 & 1 buah \\
\hline $\begin{array}{l}\text { Pipa penahan pipa } 3 / 4 \text { " } \\
\text { bag.bawah }\end{array}$ & Pipa Stainlessteel & Dia 1/2 "; 1850 & SS-304 & 1 buah \\
\hline
\end{tabular}

\section{HASIL DAN PEMBAHASAN}

Gambar 4 menyajikan metodologi pelaksanaan Teknologi pembuatan alat pencuci/pencelupan pewarna batik, untuk menghasilkan alat yang memenuhi syarat terkait dengan hasil. Identifikasi hasil yang di inginkan pada implementasi teknologi alat pencuci/pencelupan pewarna batik ke UKM dijelaskan sebagai berikut:

Tingkat pengenalan kebutuhan teknologi alat pencuci/pencelupan pewarnaan batik merupakan tahap awal detail desain menggunakan metode prosedur umum perancangan elemen-elemen mesin. Menurut Paryanto et al. (2017), tahap ini dilakukan untuk mendapatkan dan mengumpulkan data sebanyak- banyaknya untuk mendesain detail dari alat pencuci/pencelupan pewarnaan batik. Susunan komponen pada teknologi alat didapatkan dari pemikiran gabungan UKM dengan team pengabdi Universitas Negeri 
Malang (UM), terdapat enam komponen material utama yang penting dipilih dalam Tabel 1 untuk di produksi/dibuat di bengkel pengelasan oleh team pengabdi.

Tingkat penentuan mekanisme desain teknologi alat pencuci/pencelupan pewarnaan batik, dilakukan detail design ini ada dua mekanisme penting yaitu mekanisme pewarnaan kain, mekanisme penirisan kain. Konsep yang digunakan untuk mekanisme pewarnaan kain yaitu kain diletakan pada sebuah bejana drum setengah lingkaran yang telah berisi cairan pewarna (sekitar 15 liter) dihubungkan dengan rangka pipa SS 304 bagian atas yang berbentuk (huruf " $X$ ") dan rangka pipa SS 304 bagian bawah kain tercelup sebagian sekitar $20 \mathrm{~cm}$ dengan tuas diputar berulang kali. Bertujuan agat saat proses pewarnaan kain merata di seluruh permukaan kain. Mekanisme penirisan kain yang digunakan adalah dengan cara memutar rangka (huruf " $X$ ") dengan tuas, kain tersebut hingga terangkat di atas permukaan bak. Mekanisme yang terpilih untuk memindahkan kain antar bak adalah dengan cara mengganti/menguras air di lubang keluaran drum bagian bawah ke bejana lain (bak).

Momen torsi yang bekerja pada alat didapatkan setelah ditentukannya mekanisme yang digunakan. Analisa perhitungan momen torsi sederhana dipengaruhi oleh jarak tuas dan beban yang diputar yaitu saat melakukan penirisan kain, hal ini mekanisme yang digunakan adalah dengan cara memutar tangkai tuas yang berhubungan dengan tempatkain. Analisa perhitungan beban yang terakumulasi saat pencucian/ pewarnaan meliputi: rangkaian kain pipa [silang " $X$ "], beban berupa kain, cairan pewarna,tuas pemutar sebesar $12 \mathrm{~kg}$. Besarnya momen torsi saat beroperasi adalah $\mathrm{M}=3 \mathrm{~kg} \mathrm{~mm}$.

Pemilihan material yang dipilih untuk Teknologi alat pencuci/pewarna batik guna menentukan jenis material yang akan dipakai pada setiap komponen yang telah ditentukan. Menurut Sonawan (2010), pemilihan jenis material ini mengacu terhadap tiga faktor yaitu dari faktor ketersediaan material, faktor kesesuaian material terhadap fungsi komponen dan faktor yang ketiga adalah biaya material. Pemilihan material ini terdapat 7 material dalam Tabel 1 yang sesuai kebutuhan teknologi alat pencuci/pewarna batik.

Tingkat desain elemen-2 mesin, yaitu pemilihan jenis material merupakan desain elemen di setiap komponen terdapat 10 elemen mesin pada Tabel 2, dimaksudkan untuk menentukan material secara keseluruhan yang dapat digunakan serta ekstetika dari alat yang akan di desain.

Tingkat Detail gambar teknologi alat pencuci/pewarna batik diperlihatkan pada Gambar 6 yang akan dibuat dan diimplementasikan di UKM Batik Tulis dan batik cap Dewandaru, secara konkret dilapang.

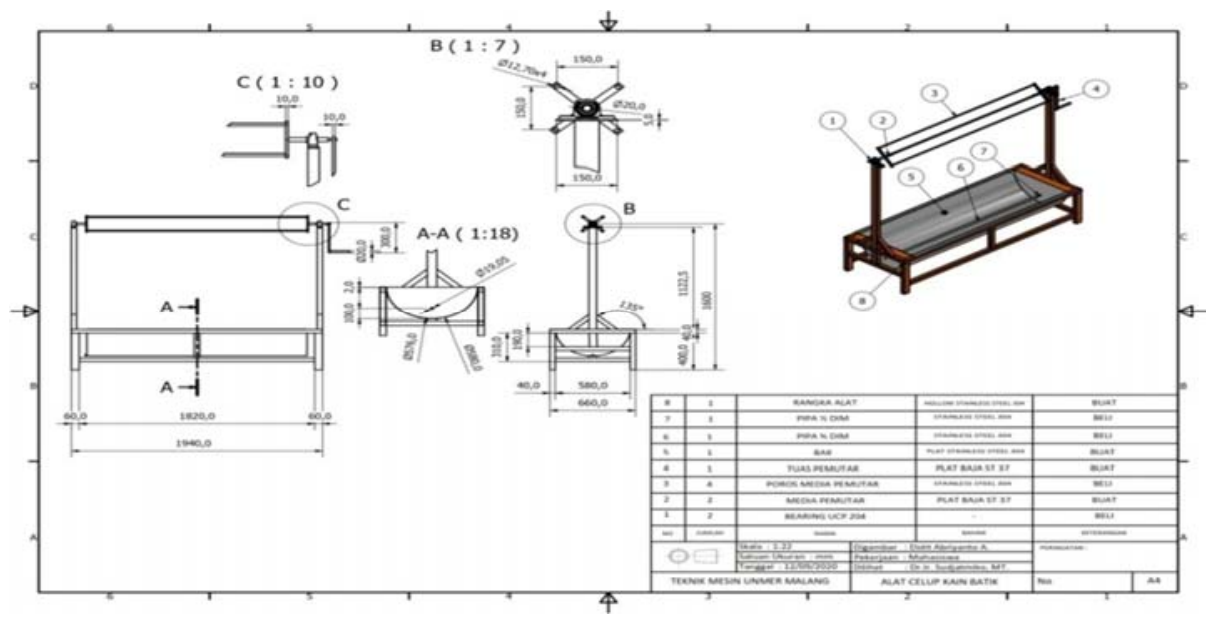

Gambar 5. Desain Teknologi Alat Pencelupan Pewarnaan Batik Sumber: Sudjatmiko (2020) 
ABDIMAS: Jurnal Pengabdian Masyarakat Universitas Merdeka Malang

Volume 5, No 3, November 2020: 228-238

Tingkat desain elemen-elemen/komponen mesin, pada tingkat ini adalah tingkatan lanjut setelah pemilihan jenis material adalah mendesain elemen di setiap komponen. Desain elemen yang dimaksud adalah menentukan tipe-tipe material yang dapat digunakan untuk membuat masing-masing komponen yang tersedia di pasaran.

Tabel 3. Tipe Material yang Digunakan Teknologi Alat Pencelupan Batik

\begin{tabular}{llcl}
\hline Nama komponen & Jenis material & Tipe material & Dimensi (mm) \\
\hline Kerangka & Besi hollow & Besi & $40 \times 40 \times 1.8$ \\
Bak & Drum-Galvanis & JIS G3302 SGCC & $560 \times 930 \times 0.65 ; 1850$ \\
Tiang penyangga & Besi hollow & Besi & $40 \times 40 \times 1.8 ; 1830$ \\
Tuas pengungkit [L] & Pipa Stainless steel & SS-304 & Dia $3 / 4 ", 165 ; 160 ; 260$ \\
Roda & Roda karet & Besi & Dia $100 \times 70$ \\
Penopang pipa kain [X] & Hollow & Besi & $30 \times 20 \times 1.8 ; 150 \times 150$ \\
Pipa penopang kain bag. atas & Pipa Stainlessteel & SS-304 & Dia 3/4"; 1700 \\
Pipa penahan kain bag. bawah & Pipa Stainlessteel & SS-304 & Dia 3/4 "; 1800 \\
Lubang pembuangan & Pipa Stainlessteel & SS-304 & Dia 3/4 ";30 \\
Pipa penahan pipa 3/4 " & Pipa Stainlessteel & SS-304 & Dia $1 / 2$ "; 1850 \\
bag.bawah & & & \\
\hline
\end{tabular}

Produksi setiap mesin atau bagian-2 konstruksi mesin haruslah dirakit sebagai sebuah unit teknologi alat pencuci/pewarna batik sebelum bisa berfungsi. Pada tingkatan ini dijelaskan urutan perakitan alat sesuai desain produk pada Gambar 6 yang telah ditentukan antara komponen yang modular dan integral, dilakukan di bengkel konstruksi pengelasan. Tabel 4 menyajikan alur perakitan Teknologi Alat Pencelupan batik.

Tabel 4. Tingkat Proses Perakitan Teknologi Alat Pencelupan Batik

\begin{tabular}{|c|c|}
\hline Urutan Proses perakitan & Fungsi \\
\hline Memasang kerangka (8) & Menyangga drum \\
\hline Memasang kedua tiang penopang & Menyangga media pemutar kain \\
\hline Memasang Bak/Drum (5) & Tempat larutan pewarna \\
\hline Memasang pipa $1 / 2^{\prime \prime}$ di bak (7) & Untuk dudukan pipa $3 / 4 "$ \\
\hline Memasang pipa 3/4" di bak (6) & Sebagai transmisi kain \\
\hline Memasang media pemutar kain(2), jumlah 4 buah & $\begin{array}{l}\text { Menyatukan antara media pemutar dengan poros pemutar } \\
\text { tempat kain }\end{array}$ \\
\hline Memasang poros media pemutar kain (3) & Tempat kain yang dicelup pewarna \\
\hline Memasang tuas pemutar (4) & Sebagai pemutar poros rangka kain \\
\hline Memasang bearing cup (1) & Sebagai dudukan poros media pemutar kain \\
\hline Memasang roda pada kaki-2 & Sebagai media pemindah alat \\
\hline
\end{tabular}

\section{Teknologi Alat Pencucian/Pencelupan Pewarnaan Kain Batik}

Pelaksanaan program kemitraan pengabdian kepada masyarakat mewujudkan peralatan teknologi alat pencucian/pencelupan pewarnaan kain batik disajikan pada Gambar 6 dan 7 (saat running test dibengkel). Tabel 5 menyajikan spesifikasi mesin pencelupan/pewarnaan batik yang akan digunakan dalam pengabdian pada UKM. 
Tabel 5. Spesifikasi Teknologi Alat Pencelupan batik

\begin{tabular}{|c|c|}
\hline Nama komponen & Dimensi/Material \\
\hline Tinggi tiang penopang rangka pemutar & $1325 \mathrm{~mm} /$ besi hollow 50x50x1.8 mm \\
\hline Rangka pipa pemutar kain & Diameter 3/4", 1.8 mm /SS-304 \\
\hline Bak/Drum & R. 550 mm/ Galvanis JIS G3302 \\
\hline Plat besi/dudukan media poros pemutar kain ["X"] & 30x20 x 1.8 mm/Baja \\
\hline Kerangka dudukan Bak drum & 50x50×1.8mm/Besi siku \\
\hline Kaki kerangka dudukan bak drum & $50 \times 50 \times 50 \times 1.8 \mathrm{~mm} /$ Besi hollow \\
\hline Tuas/Handel bentuk "L" pemutar kain & Pipa dia 3/4" "1.8mm/SS-304 \\
\hline Lubang keluaran cairan & Pipa di 1" PVC \\
\hline Panjang kerangka konstruksi alat & 1940 mm/Hollow 50x50x1.8 mm \\
\hline
\end{tabular}
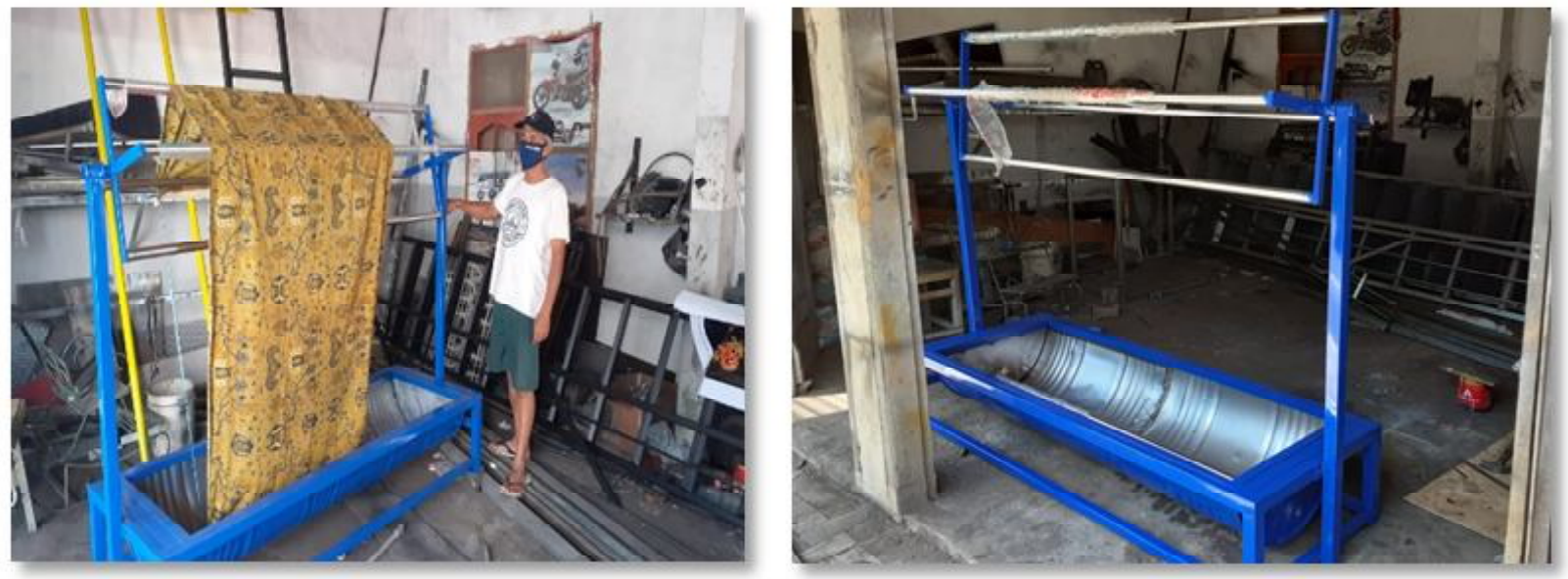

Gambar 6. Teknologi alat pencuci/pencelupan pewarnaan batik Gambar 7. Saat perakitan dan running test Teknologi alat pencuci/pencelupan pewarnaan batik di bengkel pengelasan

\section{Penerapan Teknologi Alat Pencelup dan Fiksasi}
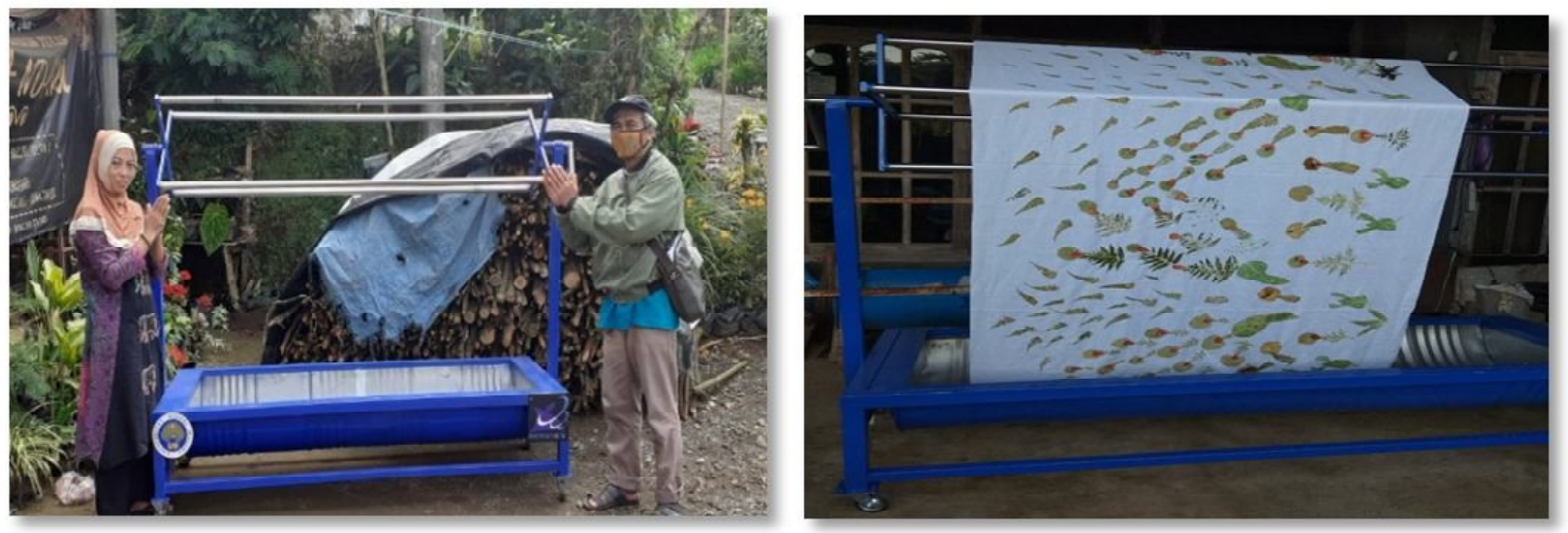

Gambar 8. Saat penyerahan Teknologi Alat Pencelupan Pewarnaan Batik

Gambar 9. Proses Pencelupan Pewarnaan dan/atau Penirisan Batik di UKM dengan Teknologi Alat Pencelupan Pewarnaan Batik 
ABDIMAS: Jurnal Pengabdian Masyarakat Universitas Merdeka Malang

Volume 5, No 3, November 2020: 228-238

Gambar 8 memperlihatkan saat penyerahan teknologi alat pencelup dan fiksasi kepada mitra UKM dilokasi desa Kampungbaru Kec. Wonosari Kabupaten Malang. Implementasi teknologi alat pencelup dan fiksasi warna terdiri atas empat bagian utama, bagian pertama adalah, drum oil berbahan dasar Galvanzied Steel Sheets JIS G3302 SGCC tebal 1.8 mm, volume efektif sebesar 15 Liter, didalamnya dilengkapi dengan roller pipa stainless steel SS 304. Bagian kedua adalah rangka terbuat dari besi siku (L40x40×3) dan besi hallow 50x50x1,25, dimensi rangka $1950 \mathrm{~mm}(\mathrm{P})$ x $670 \mathrm{~mm}(\mathrm{~L}) \times 1700 \mathrm{~mm}(\mathrm{~T})$. Bagian ketiga pipa penopang kain dengan jumlah 4 (bersilang), terbuat dari material pipa stainless steel SS 304, panjang $1870 \mathrm{~mm}$. Bagian keempat tuas pemutar, terbuat dari material pipa dia 3/4" stainless stee/ SS 304, panjang $325 \mathrm{~mm}$, berfungsi ganda selain sebagai media pemutar kain juga untuk meniriskan kain. Peniti dan karet ban sebagai alat penunjang proses pencelupan agar berjalan kontinu. Secara keseluruhan berat alat $75 \mathrm{~kg}$, dirancang lebih efektif dengan waktu proses pencelupan lebih singkat yaitu 11 menit, sebelumnya 28 menit, dengan frekuensi yang sama pencelupan 15 kali sehari. Gambar 10 memperlihatkan hasil implementasi pada alat pencelup sebagai contoh kain diberi motif kombinasi bahan alami (daun pakis dan daun jarak) ukuran kain batik 2 meter $\times 1,15$ meter. Proses pencelupan diambil rata-2/hari sebanyak 15 kali dengan 35 buah kain, sehingga kapasitas produksi 35 kain $\times 2$ meter $\times 1,15$ meter $=80,5$ $\mathrm{m}^{2}$ kain/hari.

\section{Performance Unjuk Kerja Teknologi Alat pencuci/pencelup pewarnaan}

Tabel 6 menyajikan proses pencelupan menggunakan teknologi lama (ba plastik), proses pencelupan 15 kali/hari dengan 35 buah kain, kapasitasnya produksi pencelupan 35 kain $\times 2$ meter $\times 1,15$ meter $=80,5$ $\mathrm{m}^{2}$ kain/hari.

Tabel 6. Data Pencelupan Kain Menggunakan Alat yang Lama (direndam di Bak/drum plastik)

\begin{tabular}{cccccc}
\hline $\begin{array}{c}\text { Frek. celupan } \\
\text { (kali) }\end{array}$ & $\begin{array}{c}\text { Cairan pewarna } \\
\text { (liter) }\end{array}$ & $\begin{array}{c}\text { Waktu persiapan } \\
\text { (non produktif) } \\
\text { (menit) }\end{array}$ & $\begin{array}{c}\text { Waktu } \\
\text { Produktif } \\
\text { (menit) }\end{array}$ & $\begin{array}{c}\text { Waktu } \\
\text { pengentasan } \\
\text { (menit) }\end{array}$ & $\begin{array}{c}\text { Waktu total } \\
(\mathbf{3 + 4 + 5 )} \text { (menit) }\end{array}$ \\
\hline 1 & 2 & 3 & 4 & 5 & 6 \\
2 & 10 & 2 & 10 & 4 & 16 \\
5 & 15 & 2 & 13 & 6 & 21 \\
8 & 20 & 2 & 18 & 8 & 28 \\
\hline
\end{tabular}

Tabel 7 menyajikan data pencelupan kain batik menggunakan teknologi alat baru dari hasil uji coba sendiri (UKM dengan team) dilakukan pencelupan dilakukan sebanyak tiga kali dengan frekuensi pencelupan 2,5 , dan 8 kali

Tabel 7. Data Rata-rata Pencelupan Kain Batik Menggunakan Teknologi Alat Baru

\begin{tabular}{ccccc}
\hline $\begin{array}{c}\text { Frek. celupan } \\
\text { (kali) }\end{array}$ & $\begin{array}{c}\text { Cairan pewarna } \\
\text { (liter) }\end{array}$ & $\begin{array}{c}\text { Waktu persiapan } \\
\text { (non produktif) } \\
\text { (menit) }\end{array}$ & $\begin{array}{c}\text { Waktu } \\
\text { Produktif } \\
\text { (menit) }\end{array}$ & $\begin{array}{c}\text { Waktu } \\
\text { pengentasan } \\
\text { \& penirisan } \\
\text { (menit) }\end{array}$ \\
\hline 1 & 2 & 3 & 4 & 5 \\
(3+4+5) & 3 & 3 \\
5 & 10 & 2 & 3 & 3 \\
8 & 15 & 2 & 8 & 3 \\
\hline
\end{tabular}


Tabel 6 dan Tabel 7 menunjukkan perbedaan, bahwa dengan alat yang baru dapat bekerja secara efektif dibuktikan dengan waktu pengerjaan lebih singkat 11 menit, dengan frekuensi celupan yang sama, perbedaanya pada waktu pengentasan dan penirisan yang diputar sehingga hasilnya lebih cepat bisa dibanding dengan diperas. Jam oprasional di UKM rata-rata tiap hari selama 7 jam, maka UKM dapat melakukan 15 kali pencelupan dalam sehari dengan menggunakan alat baru. Perbedaan ini ditinjau dari waktu produktif dan waktu pengetasan, penirisan, selisih 50\% (9 menit) terhadap alat lama. Jumlah 35 buah kain, kapasitasnya produksi pencelupan 35 kain $\times 2$ meter $\times 1,15$ meter $=80,5 \mathrm{~m}^{2}$ kain/hari. Perbandingan menggunakan alat lama (bak plastik) dengan teknologi alat baru proses pencelupan kain berdasarkan wawancara dengan pemilik/operator di UKM Dewandaru batik, bahwa alat lama saat proses pencelupan volume zat warna alami yang terbuang lebih banyak. Hal ini disebabkan pada saat proses penirisan/ pengeringan tidak dilakukan dan langsung penjemuran memakan waktu cukup lama, berdampak pada sisa zat warna yang tidak terserap pada kain terbuang.

Gambar 10 merupakan hasil perbandingan warna menggunakan alat yang lama (sebelah kiri) dan teknologi alat baru (sebelah kanan), tampak terjadi perubahan kualitas hasil dari proses celupan bahwa sedikit sekali kerutan pada kain jika dibanding yang menggunakan alat lama. Selain itu, waktu pengerjaan bisa lebih cepat serta perajin lebih mudah dalam melakukan pewarnaan karena postur tubuh tidak perlu membungkuk untuk merendam kain di dalam bak.
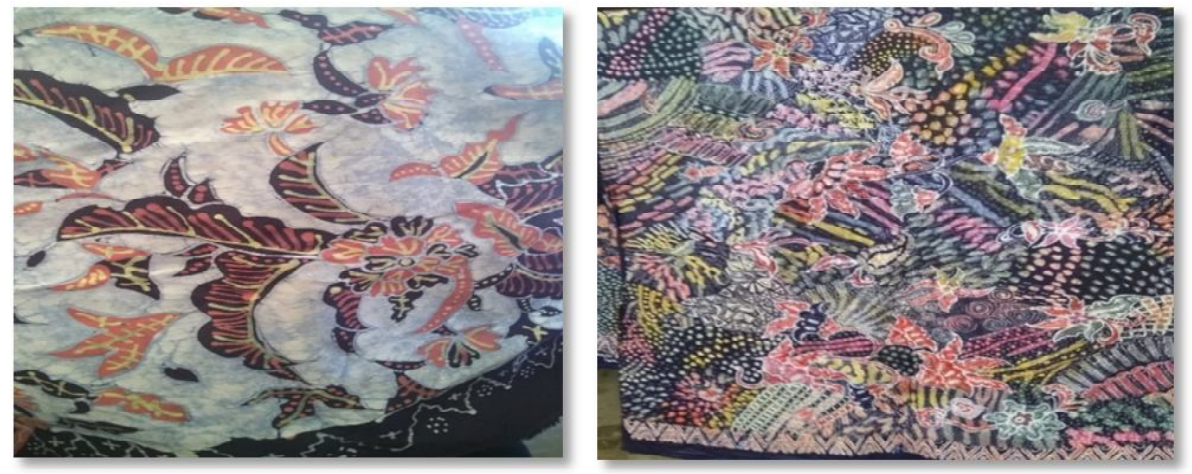

Gambar 10. Hasil perbandingan pewarnaan antara teknologi lama dan baru

\section{SIMPULAN DAN SARAN}

\section{Simpulan}

Secara keseluruhan berata total teknologi alat pencelup dan fiksasi $75 \mathrm{~kg}$, dirancang terdiri atas empat bagian utama, bagian pertama adalah, drum dengan volume efekti 20 liter. Bagian kedua adalah rangka terbuat dari besi siku, besi hallow, dimensi rangka $1940 \mathrm{~mm}(\mathrm{P})$ × $660 \mathrm{~mm}(\mathrm{~L})$ × $1600 \mathrm{~mm}(\mathrm{~T})$. Bagian ketiga pipa penopang kain dengan jumlah 4 (bersilang), terbuat dari material pipa diameter $3 / 4$ "stainless stell SS 304. Bagian keempat pemutar, terbuat dari material pipa stainless stell SS 304, panjang $325 \mathrm{~mm}$. Didesain lebih efektif dengan waktu proses pencelupan lebih singkat 11 menit, sebelumnya 28 menit, dengan frekuensi pencelupan yang sama 15 kali sehari. Perbedaan ini ditinjau dari waktu produktif dan waktu pengetasan, penirisan, selisih 50\% (9 menit) terhadap alat lama. Hasil implementasi dengan alat yang baru jumlah 35 buah kain, kapasitasnya produksi pencelupan 35 kain $\times 2$ meter $\times 1,15$ meter $=80,5$ $\mathrm{m}^{2}$ kain/hari. 
ABDIMAS: Jurnal Pengabdian Masyarakat Universitas Merdeka Malang

Volume 5, No 3, November 2020: 228-238

\section{Saran}

Untuk memperbaiki sistem manajemen pemasaran perlu dukungan dengan sistem on line, mengingat kebutuhan masyarakat dengan IT, juga memperbanyak motif batik yang mengikuti konsumen. Diperlukan prasana pendukung yang memadai menuju wisata batik di Kecamatan Wonosari yang bersebelahan dengan Destinasi wisata Lembah Malang Indah.

\section{DAFTAR PUSTAKA}

Hartanto, B. W., \& Subagyo, S. (2019). Kerangka kerja perencanaan pengembangan produk sebagai peningkatan daya saing industri kecil menengah. Jurnal Teknosains, 8(1), 26-38. https://doi.org/10.22146/teknosains.35574

Sonawan, H. (2010). Perancangan Elemen Mesin. Penerbit PT. Alfabeta. Bandung.

Ma'ruf, F., \& Prasetya, A. (2015). Modifikasi alat pencelup batik secara mekanis pada proses pembuatan batik tulis guna meningkatkan kualitas warna. Teknika STTKD: Jurnal Teknik, Elektronik, Engine, 2(1), 41-49.

Nasfiendry. (2003). Diktat Perencanaan dan Perancangan Produk. PT. Gramedia Pustaka, Jakarta.

Nurfajriah, R. A. (2017, 08 November). Perancangan Alat Pencelupan Kain Batik yang Ergonomis di Sentra Batik Bogor Tradisiku. Seminar Nasional Teknik Industri Universitas Gadjah Mada, Yogyakarta.

Arifati, R. (2017). Re-design alat pencelupan kain batik untuk mengurangi resiko Musculoskeletal Disorders (MSDs) menggunakan metode ergonomi. Jurnal Citra Widya Edukasi, 9(3), 265-274.

Paryanto, P., Zamara, R., \& Subekhi, S. M. A. (2017). Pembuatan alat pencelupan dan fiksasi zat warna alami mangrove jenis rhizopia stylosa, mahoni, dan indigofera. Prosiding SNST Fakultas Teknik, 1(1).

Pratama, F. R. D., Anugraha, R. A., \& Syafrizal, T. (2015). Pengembangan detail desain meja pencelupan di workstation perwarnaan di rumah batik. eProceedings of Engineering, 2(2).

Primadhyta, S. (2015). Menteri Gobel bakal larang impor batik. CNN Indonesia. Diakses dari https://www.cnnindonesia.com/ekonomi/20150411153228-78-45910/menteri-gobel-bakallarang-impor-batik

Susilaning, L., Hastuti, S., \& Eddy, A. A. (2010). Rekayasa alat pencelup serat alam non tekstil (SANT).

Ulrich, K. T., \& Eppinger, S. D. (2012). Product Design and Devlopment. McGraw Hill International Edition. 